\title{
Meta-analysis of lactation performance in dairy cows receiving supplemental dietary methionine sources or postruminal infusion of methionine
}

\author{
G. I. Zanton, G. R. Bowman, M. Vázquez-Añón, ${ }^{1}$ and L. M. Rode \\ Novus International Inc., St. Charles, MO 63304
}

\section{ABSTRACT}

The objectives of our study were to evaluate the productive response to methionine supplementation in lactating dairy cows and to define a relationship between metabolizable Met (MP Met) intake and production. A database of 64 papers meeting the selection criteria was developed evaluating postruminally infused DL-methionine (9 papers with 18 control diets and 35 treatment comparisons), 2-hydroxy-4-methylthio butanoic acid (HMTBa) provided as either a liquid or Ca salt form (17 papers with 34 control diets and 46 treatment comparisons), Mepron (Evonik Industries, Essen, Germany; 18 papers with 35 control diets and 42 treatment comparisons), and Smartamine (Adisseo Inc., Antony, France; 20 papers with 30 control diets and 39 treatment comparisons). Dietary ingredients and their accompanying nutritional compositions as described in the reports were entered into the CornellPenn-Miner software to model the diets and to predict nutrients that were not reported in the original publication. Data were analyzed using a weighted analysis of response to supplementation compared with the intraexperiment control, as well as through a regression analysis to changing dietary MP Met. Data included in the analysis were from experiments published between 1970 and 2011 with cows supplemented with between 3.5 and $67.9 \mathrm{~g}$ of Met or its equivalent from HMTBa. Cows supplemented with Smartamine consumed more, whereas cows supplemented with Mepron consumed less DM compared with controls. Milk yield did not significantly respond to Met supplementation, although it tended to increase for cows supplemented with HMTBa and Mepron. Milk protein yield was increased due to supplementation from all sources or from infusion, and protein concentration was greater for all supplements or infusion of DL-Met, except for cows supplemented with HMTBa. Irrespective of Met source, milk protein yield increased $2.23 \mathrm{~g}$ of protein/g of MP Met until reaching

Received April 9, 2014.

Accepted August 7, 2014.

${ }^{1}$ Corresponding author: Mercedes.vazquez@novusint.com the breakpoint. Milk fat yield was increased for Mepron and HMTBa, whereas milk fat concentration was increased for infused DL-Met and for cows supplemented with HMTBa. Based on regression analysis, response of milk fat yield to Met supplementation was not different for infused DL-Met, Mepron, and Smartamine (1.87 g of fat/g of MP Met), whereas the response to HMTBa was significantly greater at $5.38 \mathrm{~g}$ of fat/g of MP Met. Key words: methionine, lactation, 2-hydroxy-4-methylthio butanoic acid (HMTBa)

\section{INTRODUCTION}

Feeding the lactating dairy cow for optimum performance and efficiency has become increasingly more sophisticated as knowledge of the nutrient requirements of cows has increased (NRC, 2001). A component of this increased knowledge and sophistication has been in the area of AA nutrition. As environmental regulation, high feed costs, and periodic ingredient scarcity become increasingly important drivers of nutritional management decisions, a greater emphasis on AA nutrition will be required. Methionine is usually considered one of the first limiting AA for milk protein synthesis (Schwab et al., 1992; Rulquin et al., 1993; NRC, 2001). As with many AA, Met has several metabolic fates in addition to its role in protein synthesis, such as in trans-sulfuration and methylation reactions resulting in cysteine (Brosnan and Brosnan, 2006) and choline synthesis (Emmanuel and Kennelly, 1984).

To successfully provide metabolizable AA to the cow, synthetic sources of Met are often supplemented; these synthetic sources must be protected from rumen degradation. Two methods of protecting Met from ruminal degradation have been used successfully: chemically differentiated Met hydroxy analog in a form of 2-hydroxy-4-methylthio butanoic acid (HMTBa) and physically encapsulated DL-Met. Responses to increasing metabolizable Met have often, though not always, resulted in improvements in productive performance (Rulquin et al., 1993). This variability of response may be due to the variety of factors affecting Met require- 
ment, including the presence of other limiting AA (Varvikko et al., 1999) and stage of lactation (Schwab et al., 1992; Socha et al., 2008). An additional complication in assessing the effectiveness of supplemental MP Met is the response variable measured to determine the effect of supplementation (Patton, 2010). That is, changes in concentration of a milk component may or may not translate into comparable changes in yield of that component.

To arrive at the requirement for MP Met, the NRC (2001) combined results from experiments in which a variety of physically encapsulated DL-Met supplements or DL-Met infusion treatments were studied; other analyses have been conducted similarly (Rulquin et al., 1993; Vyas and Erdman, 2009). Whereas grouping responses across sources can result in broad conclusions about the effectiveness of MP Met supplementation, information about the effectiveness of the individual available sources is lost. Patton (2010) addressed this in a recent meta-analysis in which responses due to supplementation with Mepron (Evonik Industries, Essen, Germany) and Smartamine (Adisseo Inc., Antony, France) were differentiated in the analysis and different inferences were made for each of the supplements. Analysis of only experiments in which DL-Met is infused postruminally could yield important insight into the magnitude of the expected response from supplemental sources that would be fed. Also missing from previous analyses are experiments that evaluated the use of HMTBa as a source of supplemental MP Met. Whereas the rumen escape of HMTBa has been debated in the literature (Koenig et al., 2002; Noftsger et al., 2005; Zanton et al., 2012), the production effects of HMTBa have been extensively investigated. However, a comprehensive estimate of the effectiveness of supplementation is unavailable for lactating dairy cows. Therefore, in the current study, an analysis of the productive responses to supplemental Met feeding from commercially available sources was conducted with reference to the expectation observed through DL-Met infusion experiments. The objectives were to evaluate the productive response to Met supplementation in lactating dairy cows and to define a relationship between increasing MP Met intake and production.

\section{MATERIALS AND METHODS}

\section{Literature Search, Selection Criteria, and Diet Evaluation}

To accomplish the objectives of the current study, literature relating to the Met nutrition of lactating dairy cows was identified through searching the Nerac Inc. (Tolland, CT) database (1960-2009), a Google Scholar search (through December 2012), and references from published meta-analyses (Rulquin et al., 1993; NRC, 2001; Doepel et al., 2004; Vyas and Erdman, 2009; Patton, 2010; Robinson, 2010). Search scope was initially broad to enroll as many candidate papers as could be identified to be subjected to the selection criteria, which included (1) publication in a peer-reviewed journal; (2) the amount of HMTBa and physically encapsulated DL-Met fed or the amount of DL-Met infused; (3) milk production and at least 1 milk component of dairy cows were the primary outcome measurements of the studies; (4) an appropriate control diet was included (the same diet as fed to the supplemented cows without supplemental Met source); and (5) sufficient information to allow for diet modeling including DMI. The analysis was limited to the following sources of supplemental Met: postruminally infused DL-Met, HMTBa provided as either liquid or in Ca salt form (e.g., Alimet, MFP, or MHA from Novus International, St. Charles, MO), Mepron, and Smartamine. Excluded from the analysis were jugular-infused Met or HMTBa, the isopropyl ester of HMTBa (HMBi), and Ketonin due to the limited database available at the time of analysis.

Dietary ingredients and their accompanying nutritional compositions as described in the reports were entered into Cornell-Penn-Miner software (CPM Version 3.0.10; Cornell University, Ithaca, NY; University of Pennsylvania, Philadelphia, PA; Miner Institute, Chazy, NY) to model the diets. The use of CPM-Dairy allowed prediction of a broad spectrum of nutrients, such as metabolizable Lys and MP Met that may not have been reported in the original publication. When the chemical composition of forages or other ingredients were reported in the original publication, a similar ingredient was edited with the chemical composition of the reported ingredient. When the chemical composition was not reported in the publication, a similar ingredient was selected from the CPM-Dairy feedbank library as long as the final CPM-Dairy prediction for ration $\mathrm{CP}$ or NDF was within $10 \%$ of the reported value.

Actual milk production and composition were entered in the CPM-Dairy session. Milk protein was assumed to be CP unless it was obviously stated as true protein. Crude protein was assumed to contain $93 \%$ true protein (NRC, 2001). If unreported, milk component yield or concentration was calculated based on other reported information present in the original publication. If insufficient information existed in the original publication to calculate unreported data with confidence it was considered missing data for the analysis of that component. This situation only occurred for milk protein; if the milk protein data were missing, a milk CP of $3.0 \%$ was used for dietary modeling. 
Due to the limited availability of the information for the variables that describe animal, environmental, and management conditions, default settings were defined for each variable. The animal settings were second lactation, nonpregnant, $37 \mathrm{mo}$ in age, $605 \mathrm{~kg}$ of $\mathrm{BW}, 3.0$ BCS, and $0.0639 \mathrm{~kg} / \mathrm{d}$ of growth. Environmental settings were current and previous temperature of $20^{\circ} \mathrm{C}$, humidity of $50 \%$, mud depth (0), hair depth (0.63), hide (thin), and some mud on lower body for hair coat. Management setting used was tiestall barns. Days in milk used in the model reflected the average DIM during the trial as reported in the original paper.

A total of 64 papers were identified that met the selection criteria: 9 for DL-Met with 18 control diets and 35 treatment comparisons, 17 for HMTBa with 34 control diets and 46 treatment comparisons, 18 for Mepron with 35 control diets and 42 treatment comparisons, and 20 for Smartamine with 30 control diets and 39 treatment comparisons. Several papers made direct comparisons between the different sources (Rulquin et al., 2006; Benefield et al., 2009; Chen et al., 2011); these are included in the database with the supplemented diets and the appropriate control diets within the supplement source category. Prior to statistical analysis, dietary characteristics were screened to evaluate the accuracy of entered information and the presence of potentially influential observations. Two control diets were predicted by CPM formulation to be considerably distinct in either Met or Lys (\% MP; Polan et al., 1991: Smartamine; Weekes et al., 2006: DL-Met), each of which were over 4 SD separated from the mean of all other control diets. These papers were excluded from subsequent analysis. A complete listing of the papers included in the analysis and a brief description of the experiments are included in Appendix Table A1 and a summary description by source is included in Table 1.

\section{Summary and Statistical Analysis for the Productive Response to Supplementation}

Dietary characteristics from CPM evaluation of the control diets for the experiments studying the effects of the different Met supplements are summarized as the unweighted mean, standard deviation, minimum, median, and maximum. Differences among the control diets used for the different supplements were evaluated in the mixed procedure of SAS Institute (2011), with each control diet serving as the experimental unit and the source of the supplement serving as the only independent variable.

Production variables for the cows fed the control diets were summarized by raw, unweighted mean, standard deviation, minimum, median, and maximum using the methodology previously described for dietary characteristics. Weighted average of production responses entering the analysis were weighted by the square root of the number of cows receiving the supplemented diet. This weighting methodology was adopted to attempt to account for the heterogeneity among experiments (St-Pierre, 2001), whereas balancing the fact that a significant proportion of the observations were derived from crossover experiments that may have different variance structure than those experiments that were longitudinal (Lean et al., 2009). Responses were considered significant when $P<0.05$ and trending toward significance when $P<0.10$.

\section{Production Response to Increasing MP Met Supplementation}

To evaluate the production response to increasing levels of supplemental MP Met (g/d; Doepel et al., 2004; Vyas and Erdman, 2009), milk protein yield was regressed against total MP Met intake (sum of MP Met predicted from microbial protein, RUP, and supplements). The percent of total Met intake that was considered to contribute to MP Met supply was predicted by CPM-Dairy using the default values for rumen escape and intestinal digestibility. This resulted in 40,75 , and $80 \%$ of Met intake contributing to MP Met for HMTBa, Mepron, and Smartamine, respectively. Infused DL-Met was assumed to be 100\% MP Met (Doepel et al., 2004). Different modeling procedures were explored (linear breakpoint, exponential plateau, and logistic) and the linear breakpoint model (linear response to MP Met intake up to the breakpoint, after which the response to additional Met is zero) was found to provide as good a fit to the data as other nonlinear methods evaluated, as indicated by the value of the loglikelihood. Breakpoint analysis on milk protein yield was conducted in the NLMixed procedure of SAS with a fixed effect of MP Met intake and random effect of trial (Robbins et al., 2006). Random effect of trial was found significant for the linear slope and the maximum production parameters, but not for the breakpoint:

$$
\begin{aligned}
& \text { When MP Met }>\left(R+R_{(k)} z_{k}\right) \text {, then } Y_{i j}= \\
& \qquad\left(B_{o}+B_{o(k)} z_{k}+b_{o i}\right)+e_{i j} \text {; and }
\end{aligned}
$$

When MP Met $<\left(R+R_{(k)} z_{k}\right)$, then $Y_{i j k}=$

$$
\begin{gathered}
\left(B_{o}+B_{o(k)} z_{k}+b_{o i}\right)+\left(B_{1}+B_{1(k)} z_{k}+b_{1 i}\right) \\
\quad \times\left[\text { MP Met }-\left(R+R_{(k)} z_{k}\right)\right]+e_{i j k},
\end{gathered}
$$

where $Y_{i j k}=$ milk protein yield for trial $i$, observation $j$ within trial $i$, and Met source $k$ within trial $i$; 


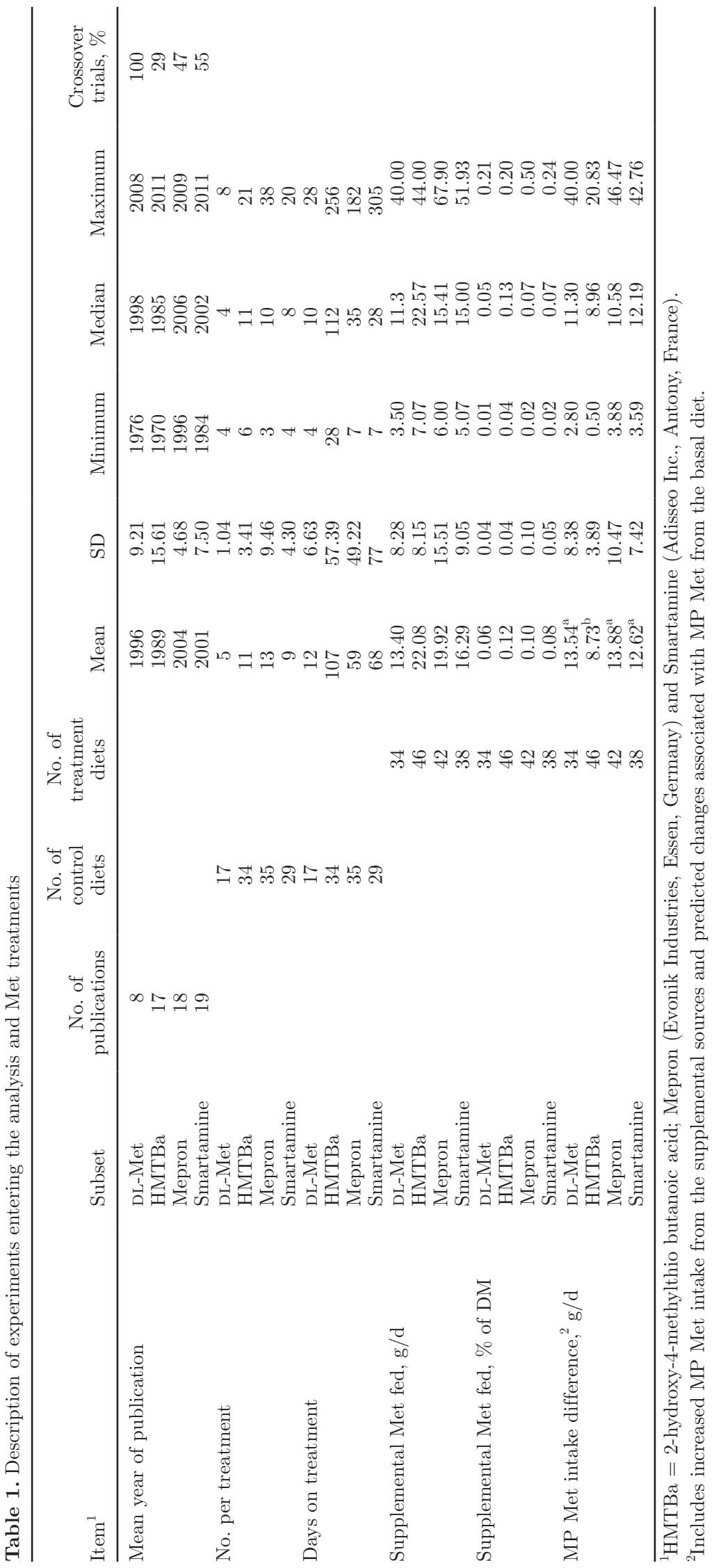


$R=$ predicted MP Met at the breakpoint across Met sources; $R_{(k)}=$ fixed effect deviation in response due to supplementation with $k$ Met source; $B_{o}=$ predicted maximum milk protein yield across Met sources; $B_{o(k)}=$ fixed effect deviation in predicted maximum milk protein yield due to supplementation with $k$ Met source; $B_{1}=$ predicted slope coefficient; $B_{1(k)}=$ fixed effect deviation in predicted slope coefficient due to supplementation with $k$ Met source; $z_{k}=$ indicator variable associated with Met source with $\Sigma z_{k}=0 ; b_{o i}=$ random effect of trial $i$ on maximum milk protein yield; $b_{1 i}=$ random effect of trial $i$ on the slope; $e_{i j k}=$ residual error for trial $i$, observation $j$ within trial $i$, and Met source $k$ within trial $i$.

With

$$
\left[\begin{array}{l}
b_{o i} \\
b_{1 i}
\end{array}\right] \sim N\left(\left[\begin{array}{l}
0 \\
0
\end{array}\right],\left[\begin{array}{cc}
\sigma_{b_{o}}^{2} & \sigma_{b_{o} b_{1}} \\
\sigma_{b_{1} b_{o}} & \sigma_{b_{1}}^{2}
\end{array}\right]\right)
$$

and

$$
e_{i j k} \sim N\left(0, \sigma_{e}^{2}\right)
$$

within the breakpoint model, the slope of the response indicates the marginal response to increasing intake of MP Met from both the basal diet prediction and the supplemental MP Met and will be interpreted as the production response obtainable due to increased supplementation with MP Met from the different sources.

A similar model was tested to evaluate the response in milk fat production to increases in MP Met supply. Nonlinear or breakpoint analysis was not able to be fit to the data due to nonsignificant nonlinearity within the range of MP Met entering the analysis. As such, a linear, mixed effects regression model was used to evaluate the response in milk fat yield to increases in
MP Met. For both protein and fat yield, regression coefficients were estimated for all sources simultaneously through analysis of covariance. Analysis of covariance was employed to account for different subpopulations associated with the different sources of Met and to statistically compare responses among these sources (Gujarati, 1970) using the indicator variable approach (Suits, 1957). The implication of this analytical approach is that coefficients of the equations are calculated for the average response (across sources) to additional MP Met and the deviations from these overall coefficients are calculated for the different source groups. The statistical test for determining differences between the coefficients of the nutritional groups is then a test of whether each of these deviations is different from 0 individually or collectively.

\section{RESULTS AND DISCUSSION}

\section{Database Description}

Prior to analysis, the response in milk yield to supplemental MP Met was used to screen for outliers, which were removed if greater than $3 \mathrm{SD}$ different from the mean. Four treatment groups were found to be outliers based on this screening criterion (Polan et al., 1970; Hansen et al., 1991; Girard et al., 2005; Lara et al., 2006; Table 2). Two of these treatment groups were supplemented with HMTBa, 1 was supplemented with Smartamine, and 1 was supplemented with Mepron. Milk yield responses for these outlying treatment groups were greater than $4 \mathrm{~kg}$ increase or decrease in milk yield, whereas the maximum difference in the remaining trials was $3 \mathrm{~kg}$.

Description of the papers, experiments, and supplementation levels are provided in Table 1. Experiments evaluating the effects of DL-Met and HMTBa began with lactating dairy cows in the 1970s and continued

Table 2. Outlying observations based on studentized residuals of milk yield response ${ }^{1}$

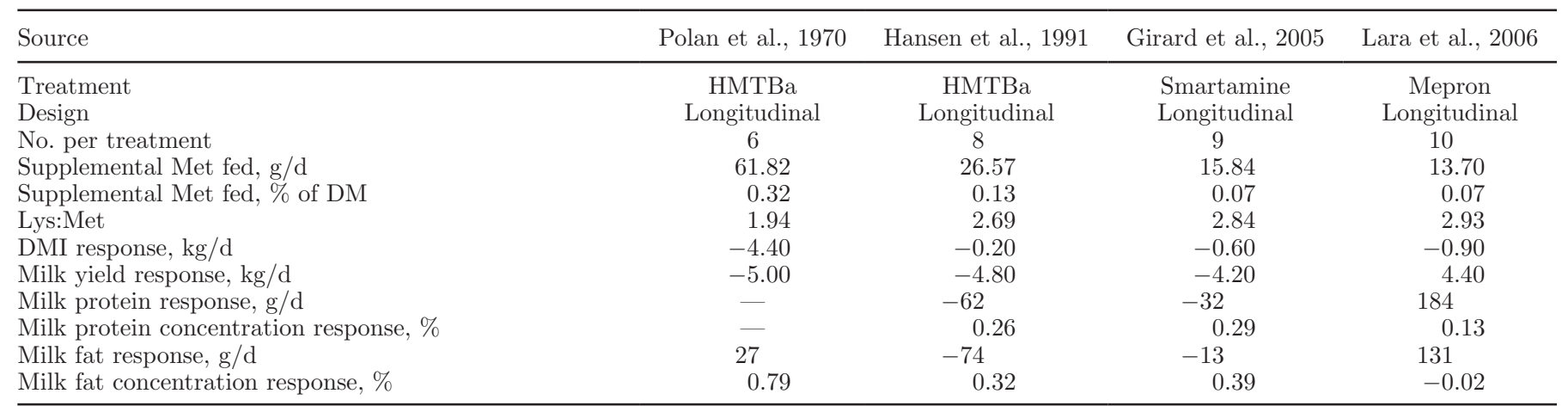

${ }^{1} \mathrm{HMTBa}=$ 2-hydroxy-4-methylthio butanoic acid; Mepron (Evonik Industries, Essen, Germany) and Smartamine (Adisseo Inc., Antony, France). 
through current literature. In contrast, Mepron and Smartamine literature is much more recent due to the later development of these products. Nevertheless, we found a similar number of publications studying the effects of HMTBa, Mepron, and Smartamine and similar numbers of supplemented diets. Overall, trials evaluating the responses of cows to HMTBa supplementation were longer in duration that the other 2 dietary supplements and had a fewer proportion of trials employing crossover designs. Trials evaluating Mepron and Smartamine were intermediate in duration and were roughly split between trials employing crossover designs and those that were longitudinal in nature. Infusion studies were all crossover trials and of short duration. The extents to which these experimental considerations affect the results obtained in this analysis are unknown. Benefield et al. (2009) determined that the duration of the response period could affect the magnitude of the response obtained with crossover experiments studying Met supplementation, with longer durations generally considered to be preferable to shorter durations of supplementation ( 1 vs. $2 \mathrm{wk}$ in that experiment). St-Pierre and Sylvester (2005) determined that significant responses in milk protein yield to the different supplements for cows fed differing Met sources were not reached until wk 5 of supplementation, although the milk protein concentration obtained significance during the first week of supplementation. Changes in milk yield were not evident in this trial until wk 7 of supplementation (St-Pierre and Sylvester, 2005). The order of treatment administration is not reported for the experiments included in the current analysis, so consideration of the extent of carryover cannot be determined. It will be assumed throughout the current analysis that the design characteristics previously discussed will not affect the magnitude of the responses evaluated, but the degree to which this assumption is tenable can only be addressed through subsequent research.

Quantity of supplemental Met supplied is shown in Table 1. As can be seen, variation is substantial between trial and Met source. The MP Met difference from basal includes any increase in MP Met intake due to supplementation and any changes provided through the basal diet due to changes in DMI. On average, cows infused with DL-Met were provided with lower levels of Met; however, as this was assumed to be $100 \%$ absorbed, MP Met differences were comparable for DLMet, Mepron, and Smartamine. Cows fed HMTBa were fed a higher amount of supplemental Met equivalent than cows fed the other sources; however, due to degradation of the product within the rumen (assuming $40 \%$ of HMTBa escaped rumen degradation; Koenig et al., 1999, 2002; Vázquez-Añón et al., 2001), predicted MP Met was not changed as much in HMTBa-fed cows.
The range of predicted MP Met supplementation was very large, with cows on treatment receiving between 0.50 to $46.47 \mathrm{~g}$ of additional MP Met/cow per day than the control cows.

Predicted characteristics of the basal diets fed to cows infused or supplemented with the Met sources are shown in Table 3. As these are model predictions, instead of analyzed nutrient characteristics, the possibility exists that variability was introduced from the model predictions; although the model predictions should not be biased among Met sources. The 2 chemical components that were most frequently reported in the original manuscripts were CP (reported for $94 \%$ of control diets) and NDF (reported for $66 \%$ of control diets). Correlation between predicted and reported values were good for CP $(r=0.915)$ and NDF $(r=0.947)$. No prediction bias was detected for $\mathrm{CP}$, but a significant negative prediction bias was noted for NDF, with NDF predicted by CPM being around $1 \%$ unit lower than reported on average. In addition, the choice of CPM as the dietary model could influence the predicted flow of MP and AA. It has been demonstrated (Pacheco et al., 2012) that CPM over-predicted the flow of microbial $\mathrm{CP}$ and all evaluated AA except leucine but underpredicted the flow of RUP. It is acknowledged that the use of CPM could have an effect on the reported flow of MP Met and the response to increasing level of MP Met from infused or supplemented sources. It is not expected, however, that a differential response would be seen between supplemental or infused sources due to the choice of CPM as the nutritional model.

Several interesting differences in the control diets among supplements deserve note. Control cows in studies with infused DL-Met or fed HMTBa had lower concentrations of dietary CP than control cows in studies with Mepron or Smartamine; for DL-Met this was due to lower concentrations of RDP, but for HMTBa this was due to lower concentrations of RUP. For HMTBa trials, control cows had higher MP Met concentrations than cows fed other supplements or infused with DL-Met. This suggests that control cows fed HMTBa might be closer to meeting the Met requirement than the control cows of other treatments (Table 3). Lysine concentration did not differ among the control diets in experiments evaluating the different supplements, although the Lys concentration was higher for DL-Metinfusion studies, which was typically accomplished by postruminal infusion of lysine in the control cows. Due to these characteristics in Lys and Met individually, the Lys-to-Met ratio was significantly lower for control cows in HMTBa studies than in the control cow diets for the other studies. Control cows in Smartamine experiments were fed diets with significantly higher levels of NDF than control cows in HMTBa experiments, 
Table 3. Description of the diets fed in studies infusing methionine or supplemented with HMTBa, Mepron, or Smartamine ${ }^{1}$

\begin{tabular}{|c|c|c|c|c|c|c|}
\hline Item & Subset $^{2}$ & Mean & SD & Minimum & Median & Maximum \\
\hline \multirow{2}{*}{$\mathrm{CP}, \%$ of $\mathrm{DM}$} & HMTBa & $15.50^{\mathrm{b}}$ & 1.99 & 11.70 & 16.00 & 18.60 \\
\hline & Mepron & $16.70^{\mathrm{a}}$ & 1.45 & 13.10 & 16.70 & 19.70 \\
\hline \multirow{3}{*}{ Reported $\mathrm{CP},{ }^{3} \%$ of $\mathrm{DM}$} & DL-Met & 14.54 & 2.53 & 10.50 & 14.40 & 18.80 \\
\hline & НMTBa & 15.58 & 2.04 & 11.50 & 16.20 & 18.40 \\
\hline & Mepron & 16.94 & 1.46 & 13.00 & 17.30 & 19.60 \\
\hline \multirow{3}{*}{ RDP, $\%$ of DM } & НMTВа & $10.55^{\mathrm{b}}$ & 1.23 & 7.87 & 10.33 & 13.22 \\
\hline & Mepron & $10.73^{\mathrm{ab}}$ & 1.08 & 8.54 & 10.55 & 13.26 \\
\hline & Smartamine & $11.35^{\mathrm{a}}$ & 1.71 & 8.54 & 11.02 & 15.59 \\
\hline \multirow[t]{4}{*}{ RUP, $\%$ of DM } & DL-Met & $4.98^{\mathrm{bc}}$ & 1.06 & 3.71 & 4.70 & 6.96 \\
\hline & HMTBa & $4.96^{\mathrm{c}}$ & 1.11 & 3.39 & 4.92 & 7.15 \\
\hline & Mepron & $5.97^{\mathrm{a}}$ & 0.81 & 4.56 & 5.97 & 8.30 \\
\hline & Smartamine & $5.56^{\mathrm{ab}}$ & 1.54 & 3.38 & 5.18 & 9.07 \\
\hline \multirow{3}{*}{ MP Lys, \% of MP } & HMTBa & $6.74^{\mathrm{b}}$ & 0.28 & 5.97 & 6.81 & 7.23 \\
\hline & Mepron & $6.66^{\mathrm{b}}$ & 0.27 & 6.12 & 6.68 & 7.26 \\
\hline & Smartamine & $6.80^{\mathrm{b}}$ & 0.21 & 6.42 & 6.78 & 7.26 \\
\hline \multirow[t]{4}{*}{ Lys:Met } & DL-Met & $3.49^{\mathrm{a}}$ & 0.33 & 2.95 & 3.57 & 4.15 \\
\hline & HMTBa & $3.20^{\mathrm{b}}$ & 0.23 & 2.85 & 3.18 & 3.82 \\
\hline & Mepron & $3.39^{\mathrm{a}}$ & 0.19 & 2.79 & 3.40 & 3.69 \\
\hline & Smartamine & $3.39^{\mathrm{a}}$ & 0.18 & 3.16 & 3.34 & 3.78 \\
\hline \multirow[t]{4}{*}{$\mathrm{NDF}, \%$ of $\mathrm{DM}$} & DL-Met & $32.73^{\mathrm{ab}}$ & 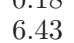 & 27.00 & $\begin{array}{r}5.04 \\
31.70\end{array}$ & $\begin{array}{r}5.10 \\
46.30\end{array}$ \\
\hline & HMTBa & $30.19^{\mathrm{b}}$ & 4.89 & 20.30 & 29.80 & 42.20 \\
\hline & Mepron & $31.42^{\mathrm{ab}}$ & 5.29 & 25.20 & 28.30 & 40.80 \\
\hline & Smartamine & $32.90^{\mathrm{a}}$ & 5.48 & 22.90 & 34.40 & 41.00 \\
\hline \multirow[t]{3}{*}{ NFC, $\%$ of DM } & DL-Met & $44.06^{\mathrm{ab}}$ & 5.92 & 32.7 & 44.5 & 53.20 \\
\hline & HMTBa & $46.41^{\mathrm{a}}$ & 6.38 & 32.00 & 47.40 & 55.10 \\
\hline & Mepron & $42.09^{\mathrm{b}}$ & 5.12 & 32.90 & 42.90 & 48.70 \\
\hline
\end{tabular}

$\overline{{ }^{a}-}$ Within an item, means with different superscripts are different at $P<0.05$.

${ }^{1}$ Predicted values from CPM Dairy (CPM Version 3.0.10; Cornell University, Ithaca, NY; University of Pennsylvania, Philadelphia, PA; Miner Institute, Chazy, NY) using ingredient analysis and production characteristics reported in the original manuscripts, except for where indicated. ${ }^{2} \mathrm{HMTBa}=2$-hydroxy-4-methylthio butanoic acid; Mepron (Evonik Industries, Essen, Germany) and Smartamine (Adisseo Inc., Antony, France).

${ }^{3}$ As reported in the original manuscripts.

with control cows in Mepron and DL-Met experiments fed intermediate levels of NDF. Nonfiber carbohydrates were higher in diets fed in HMTBa experiments. Several initial experiments involving HMTBa were designed to evaluate the effects of HMTBa to resolve a moderate milk fat depression induced by feeding a higher ratio of NFC to NDF (e.g., Hutjens and Schultz, 1971; Rosser et al., 1971), which may partially explain the higher ratio of NFC to NDF.

Control cow production and response to treatment descriptive statistics are shown in Table 4 . The primary differences seen with control cows between the studies evaluating different supplements is that in trials in which Mepron was evaluated, DMI and milk yield were greater than in trials in which the other supplements were evaluated. A portion of this difference could be ex- plained by the more recent average and minimum date of publication and, by inference, date of experimentation, where date of experimentation is coincident with increases in genetic and management potential. Milk protein concentration for control cows in the infusion studies was significantly lower than in trials evaluating Met supplements, although milk protein yield was only different for control cows in trials evaluating Mepron $(P<0.05)$. Control cow milk fat concentration was greatest in infusion trials and milk fat yield was lowest in control cows in HMTBa trials due to a combination lowest milk yield and lowest fat concentration. Milk yield production efficiency was significantly greater for control cows in Mepron experiments, whereas protein and fat productive efficiency was not different among control cows across supplement trials. 
Table 4. Control cow production reported as mean, standard deviation, minimum, median, and maximum response

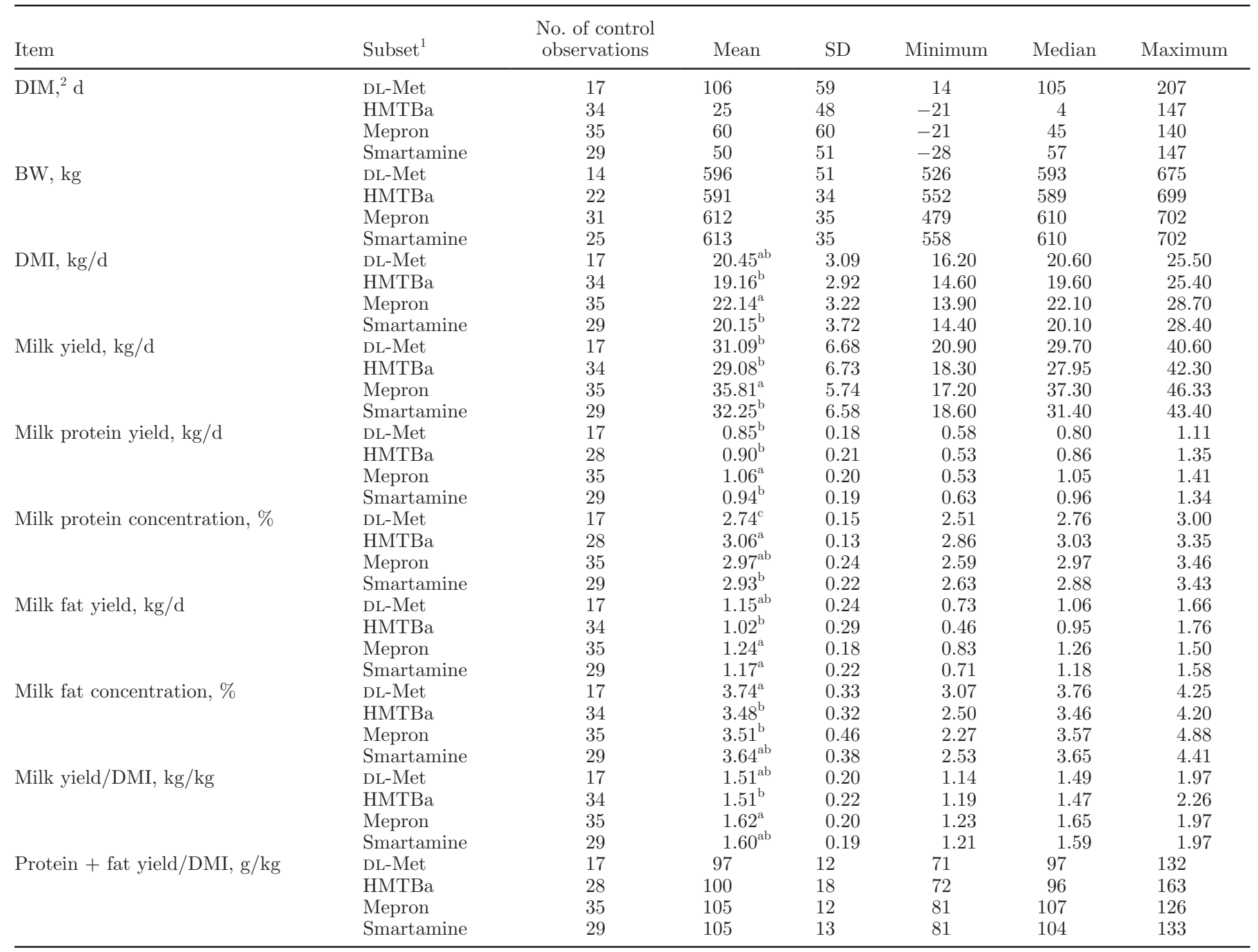

${ }^{\mathrm{a}-\mathrm{c}}$ Within an item, means with different superscripts are different at $P<0.05$.

${ }^{1} \mathrm{HMTBa}=$ 2-hydroxy-4-methylthio butanoic acid; Mepron (Evonik Industries, Essen, Germany) and Smartamine (Adisseo Inc., Antony, France).

${ }^{2}$ DIM is recorded at the beginning of supplementation, where supplementation beginning before calving is represented as negative DIM values.

\section{Response to Supplementation}

Weighted analysis of production responses to additional Met from the different sources is shown in Table 5 . Because of the uncertainty of model predictions of MP Met flow and MP Met from the supplements, the analysis of response to supplementation is provided to address the question of what happens when these Met sources are fed, irrespective of predicted MP Met status of the control or supplemented cows. The weighted analysis is used to evaluate the effects of Met and to test differences among sources to the exclusion of the unweighted analysis to account for the heterogeneity of variance that may be present across studies. Discussion of any differences due to treatment type will be restrict- ed to instances where at least one of the means is significantly different from 0 . Dry matter intake response was affected by source of Met supplementation in that cows fed Smartamine consumed significantly more DM than the respective control cows (different from $0 ; P$ $<0.02$ ) and the cows supplemented with Mepron consumed significantly less DM than the respective control cows; the cows fed the HMTBa or infused with DL-Met did not consume a different amount of DM than cows fed those control diets. Methionine is the AA that can have the greatest negative effect on DMI if overfed (Benevenga, 1974). However, for cows infused with DLMet, no significant effect on DMI was observed, from which it can be inferred that when postruminal Met is provided in the ranges given in these experiments that 
Table 5. Weighted response to additional methionine provided to cows through post-ruminal infusion with DL-Methionine or supplemented with HMTBa, Mepron, or Smartamine ${ }^{1}$

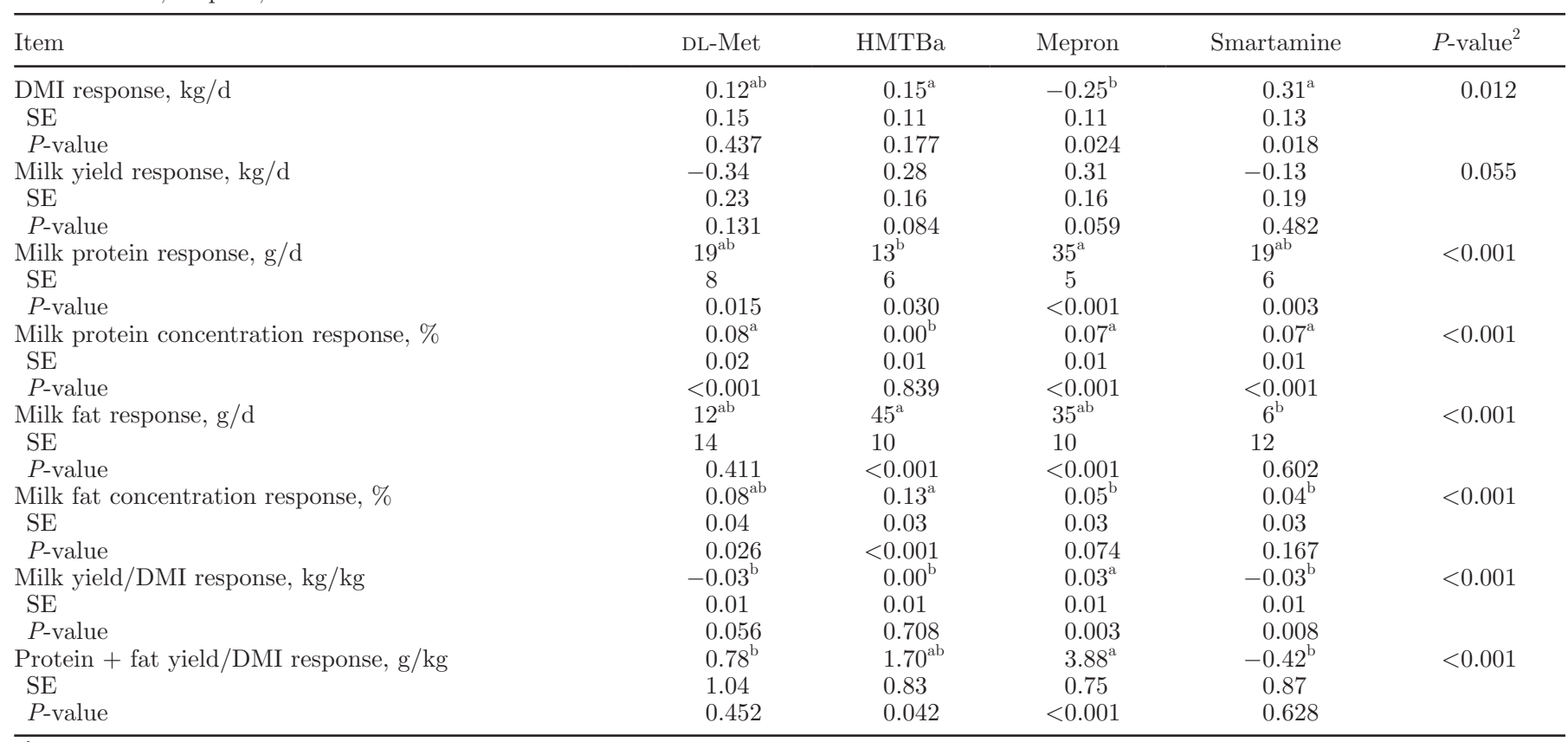

${ }^{\mathrm{a}, \mathrm{b}}$ Within a row, means with different superscripts are different at $P<0.05$.

${ }^{1} \mathrm{HMTBa}=2$-hydroxy-4-methylthio butanoic acid; Mepron (Evonik Industries, Essen, Germany) and Smartamine (Adisseo Inc., Antony, France)

${ }^{2} P$-value was associated with testing if at least 1 of the mean weighted responses differed from 0.

it is not sufficiently in excess of requirement to induce a reduction in DMI. On average, cows fed Mepron and Smartamine received a similar amount of MP Met as the cows infused with DL-Met postruminally and each other.

Overall, milk yield did not respond to MP Met supplementation irrespective of source. Numerically, cows supplemented with HMTBa or Mepron tended toward increased milk yields and cows infused with DL-Met or supplemented with Smartamine had nonsignificant decreases in milk yield. Milk protein yield was increased compared with control cow milk protein production for all Met sources evaluated $(P<0.05)$. The magnitude of the protein response was greater for Mepron compared with HMTBa; however, all other source comparisons were not different. Increasing milk protein yield is one of the most frequently observed and expected responses seen due to supplementation with protected sources of Met (Rulquin et al., 1993; NRC, 2001; Patton, 2010). The average milk protein yield responses ranged from $13 \mathrm{~g} / \mathrm{d}$ for HMTBa-supplemented cows to $35 \mathrm{~g} / \mathrm{d}$ for Mepron-supplemented cows. Patton (2010) noted a similar milk protein production increase when cows were supplemented with Mepron compared with Smartamine in a meta-analysis containing many of the same experiments evaluated in the current analysis. The magnitude of the responses found across experiments between Smartamine and Mepron has not been replicated, however, in direct comparisons with the same basal diet and level of Met supplementation (Blum et al., 1999; Benefield et al., 2009). Experiments in which DL-Met was infused postruminally were included in this analysis to estimate the magnitude of the expected response due to increasing MP Met availability to the cow. Infusing DL-Met postruminally resulted in an increase in milk protein yield of $19 \mathrm{~g} / \mathrm{d}$ compared with the control cow protein yield; each of the supplemental sources of Met was not significantly different from postruminally infused DL-Met $(P>0.05)$.

The mechanism by which each of these commercial products increases milk protein yield would appear to be different. Milk protein concentration changes are similar for cows supplemented with Mepron and Smartamine and infused postruminally with DL-Met, whereas milk protein concentration is unchanged for cows supplemented with HMTBa (Table 5). Milk protein concentration is often used as an indication of the effectiveness of a Met source leading to changes in milk protein synthesis (Schwab et al., 2001). When milk yield is unchanged, an increase in milk protein concentration will allow for an accurate inference to be made on milk protein yield and efficacy of Met supplementation; however, as is shown in the current analysis, milk protein response can be of similar magnitude without 
significant changes in milk protein concentration due to supplementation.

Milk fat yield response was significantly affected by Met supplementation with HMTBa and Mepron $(P$ $<0.001$; Table 5). Supplementing with HMTBa and postruminal infusion with DL-Met resulted in increased milk fat concentration $(P<0.05)$, whereas supplementing with Mepron resulted in a trend for increased milk fat concentration $(P<0.08)$. Response in milk fat concentration for both DL-Met and HMTBa was significantly greater than the response seen in Mepron and Smartamine. Methionine plays a role in the synthesis of coenzyme S-adenosyl methionine, which is involved in transferring methyl groups. S-Adenosyl methionine has been shown to participate in the formation of choline, carnitine, creatine, and folic acid. Emmanuel and Kennelly (1984) reported that $28 \%$ of the Met infused into lactating goats was used for choline synthesis. Methionine and choline both act as methyl donors, thereby potentially influencing milk volume and milk fat (Sharma and Erdman, 1988). McCarthy et al. (1968) further observed that supplementation with Met or its analog restored serum FA composition, indicating the use of Met in lipid transport. Additionally, Huber et al. (1984) reported higher triglycerides in the blood with HMTBa supplementation, which are key substrates for milk fat synthesis.

Milk production efficiency response (milk yield/ DMI) was significantly increased over the controls for cows supplemented with Mepron (Table 5), whereas a tendency and a significant reduction in milk production efficiency was noted for cows infused with DL-Met or supplemented with Smartamine, respectively. Cows fed HMTBa did not have different milk production efficiency compared with control cows. Milk protein and fat production efficiency was significantly increased when cows were supplemented with HMTBa and Mepron $(P$ $<0.05)$. This response was driven by the statistical increases in protein and fat yield for these supplements.

\section{Production Response to Increasing MP Met Supplementation}

Raw data for milk protein production entering the analysis is shown in Figure 1. It is clear from the visual analysis of the responses that a greater component of the difference in milk protein yield is associated with the effect of trial: within trial responses in milk protein yield to changes in MP Met are small compared with the magnitude of the differences occurring between trials. Of the statistical models that were evaluated (breakpoint, exponential, and logistic models), differences in statistical fit (log-likelihood or residual analysis) were minimal and did not provide a sufficient criteria to distinguish the differing models.

A summary of postruminal infusion studies reported that efficiencies of AA use for milk protein synthesis decreased as supply was elevated (Rulquin et al., 1993; Doepel et al., 2004; Lapierre et al., 2006), although in a recent meta-analysis coding for anticipated Met deficiency was not a significant contributor toward the response to Met supplementation (Patton, 2010). Extraction rates of AA can change depending upon the supply of AA to the mammary gland (Guinard et al., 1994). Bequette et al. (2000) determined that the extraction rate of histidine increased to 74 from $17 \%$ when histidine was removed from a postruiminal infusate compared with when histidine was included. Likewise, Guinard and Rulquin (1995) reported that extraction rate of Met increased to $58.3 \%$ when Met was not infused from $10.7 \%$ when Met was infused at $32 \mathrm{~g} / \mathrm{d}$, resulting in no change in Met uptake by the mammary gland. These diminishing returns would be more accurately represented by a continuous slope model. However, whereas continuous models may provide for a more biologically relevant description of a whole animal response (Doepel et al., 2004), due to the ease of interpretation of the breakpoint analysis with respect to supplemental source differences and to DL-Met, it was chosen as the model to characterize the response in milk protein yield to increases in MP Met.

The graphical results of this analysis are shown in Figure 2 and the parameter estimates are shown in Table 6 . Consistent with previous analyses of the response in milk protein output to increases in MP Met, response was limited at higher levels of MP Met input (NRC, 2001; Doepel et al., 2004; Vyas and Erdman, 2009). Predicted maximum milk protein yield was greater in experiments in which Mepron was evaluated, with none of the other sources differing from each other in this parameter estimate. The greater predicted maximum milk protein yield is a reflection of the greater milk protein yield of the control cows in experiments in which Mepron was evaluated (Table 4). No other differences in model parameter estimates were observed, with the slope of the response in milk protein yield to increases in predicted MP Met averaging $2.23 \mathrm{~g} / \mathrm{g}$ across sources $(P>0.10)$. Thus for each additional gram of predicted MP Met delivered, irrespective of source, an additional $2.23 \mathrm{~g}$ of milk protein would be expected to be produced. The resulting efficiency of Met capture into milk protein (assuming 2.7\% of milk true protein is Met; Waghorn and Baldwin, 1984) would be $0.062 \mathrm{~g}$ of increased milk Met per gram of increased MP Met. Doepel et al. (2004) reported a marginal efficiency of $15.3 \mathrm{~g}$ of increased milk protein per each additional 

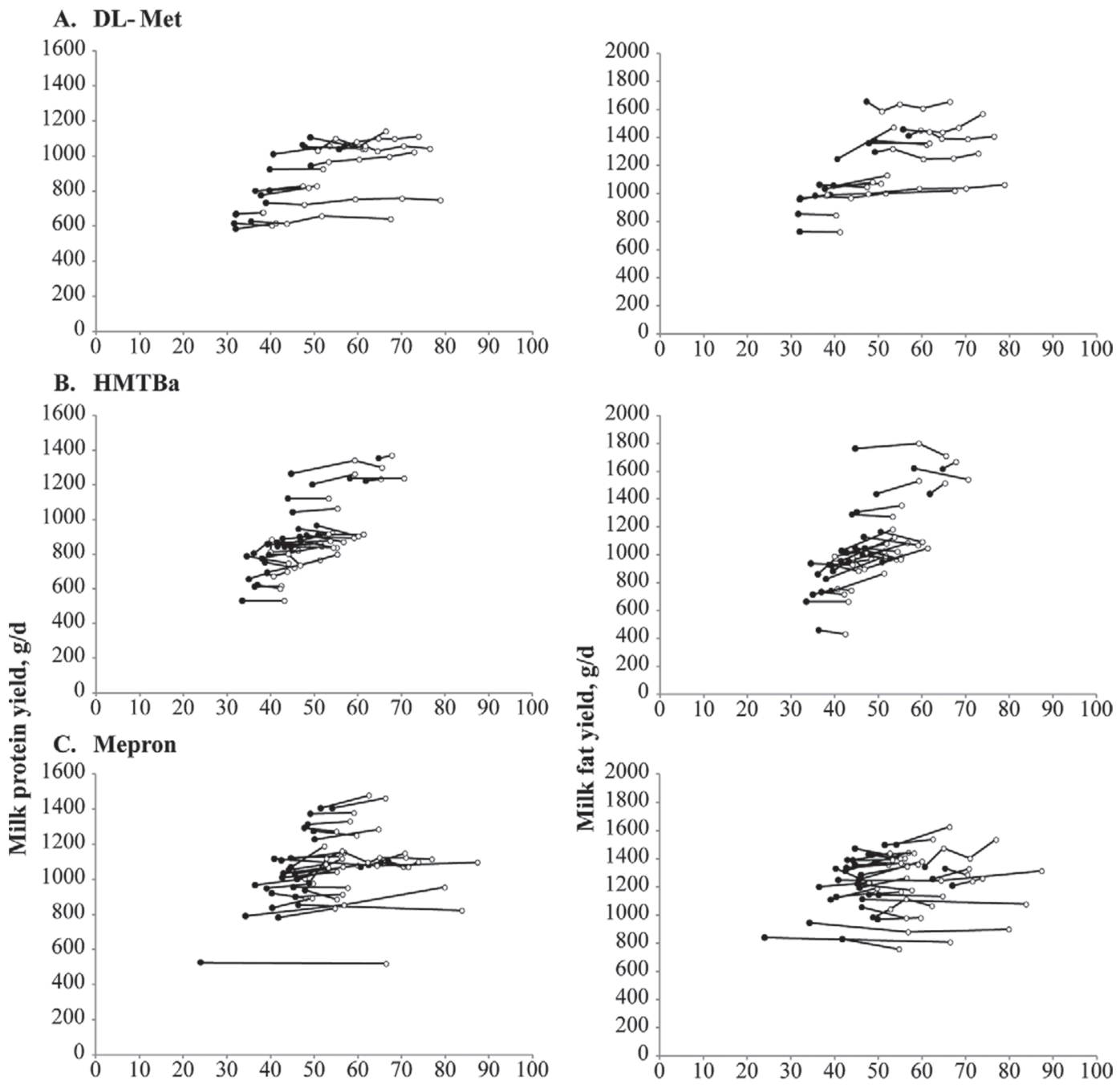

\section{Smartamine}
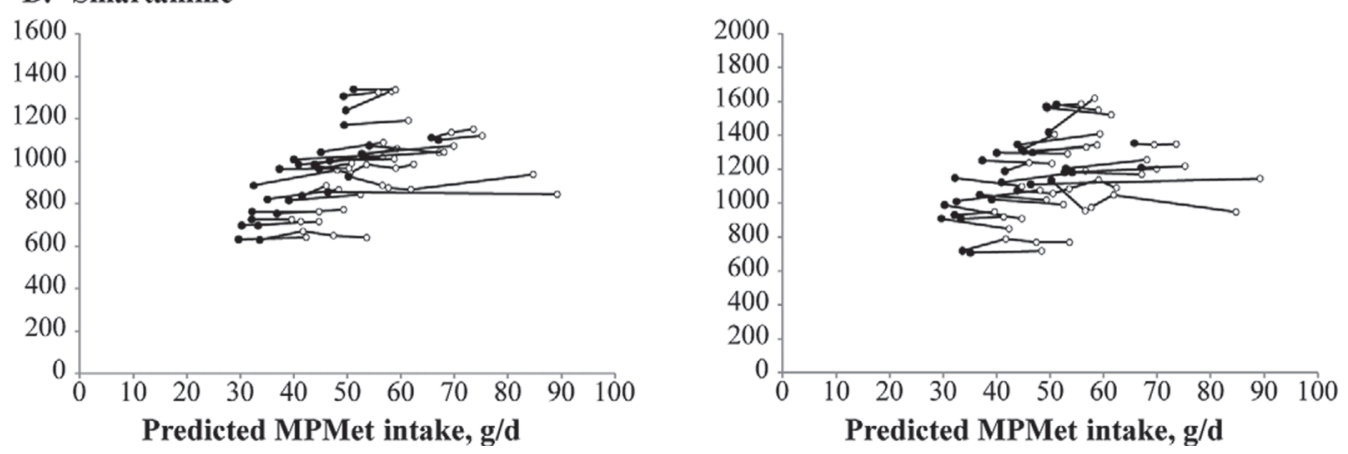

Figure 1. Response of milk protein (left panel) and milk fat (right panel) yieldS to increasing metabolizable methionine (MPMet) provided to cows through postruminal infusion with DL-Met (A) or supplemented with 2-hydroxy-4-methylthio butanoic acid (HMTBa; B), Mepron (Evonik Industries, Essen, Germany; C), or Smartamine (Adisseo Inc., Antony, France; D). Solid circles (๑) indicate the controls and open circles (O) indicate Met-supplemented groups; symbols connected by lines indicate data from cows receiving the same control diet.

gram of duodenal Met supply in a segmented linear model similar to the one used here. This translates to a marginal response of $0.415 \mathrm{~g}$ of additional milk Met per additional gram of MP Met using the assumptions employed in this analysis.
Equations put forward from meta-analyses by Doepel et al. (2004) and Vyas and Erdman (2009) result in substantially greater marginal efficiencies than that which was derived in the present meta-analysis. Doepel et al. (2004) predicted marginal efficiency of milk pro- 
Table 6. Parameter estimates of the mixed effect breakpoint milk protein yield analysis to increasing intake of metabolizable methionine (MPMet) provided to cows through post-ruminal infusion with DL-Methionine or supplemented with HMTBa, Mepron, or Smartamine ${ }^{1}$

\begin{tabular}{|c|c|c|c|c|c|c|}
\hline Item & DL-Met & HMTBa & Mepron & Smartamine & $\begin{array}{l}\text { Overall } \\
\text { estimate }^{2}\end{array}$ & $P$-value ${ }^{3}$ \\
\hline Predicted maximum, g of milk protein & $894^{\mathrm{b}}$ & $920^{\mathrm{b}}$ & $1,122^{\mathrm{a}}$ & $981^{\mathrm{ab}}$ & & \\
\hline Linear slope, $\Delta \mathrm{g}$ of milk protein $/ \Delta \mathrm{g}$ of metabolizable Met & 1.69 & 1.73 & 2.86 & 2.63 & 2.23 & \\
\hline $\mathrm{SE}$ & 0.64 & 0.73 & 0.54 & 0.64 & 0.33 & 0.801 \\
\hline$P$-value & 0.010 & 0.020 & $<0.001$ & $<0.001$ & $<0.001$ & \\
\hline$P$-value & $<0.001$ & $<0.001$ & $<0.001$ & $<0.001$ & $<0.001$ & \\
\hline
\end{tabular}

$\overline{\mathrm{a}, \mathrm{b}}$ Within a row, means with different superscripts are different at $P<0.05$.

${ }^{1}$ HMTBa = 2-hydroxy-4-methylthio butanoic acid; Mepron (Evonik Industries, Essen, Germany) and Smartamine (Adisseo Inc., Antony, France).

${ }^{2}$ Parameter estimate for the overall response where methionine sources are combined when $P>0.05$.

${ }^{3} P$-values associated with the overall test of differences in parameter estimates between sources.

tein production of $15.3 \mathrm{~g}$ of increased milk protein per additional gram of estimated Met supply at the duodenum compared with the 2.23 value estimated from the breakpoint model in this analysis. The average MP Met difference between supplemented and control diets across sources were $12 \mathrm{~g}$ of MP Met in our analysis;

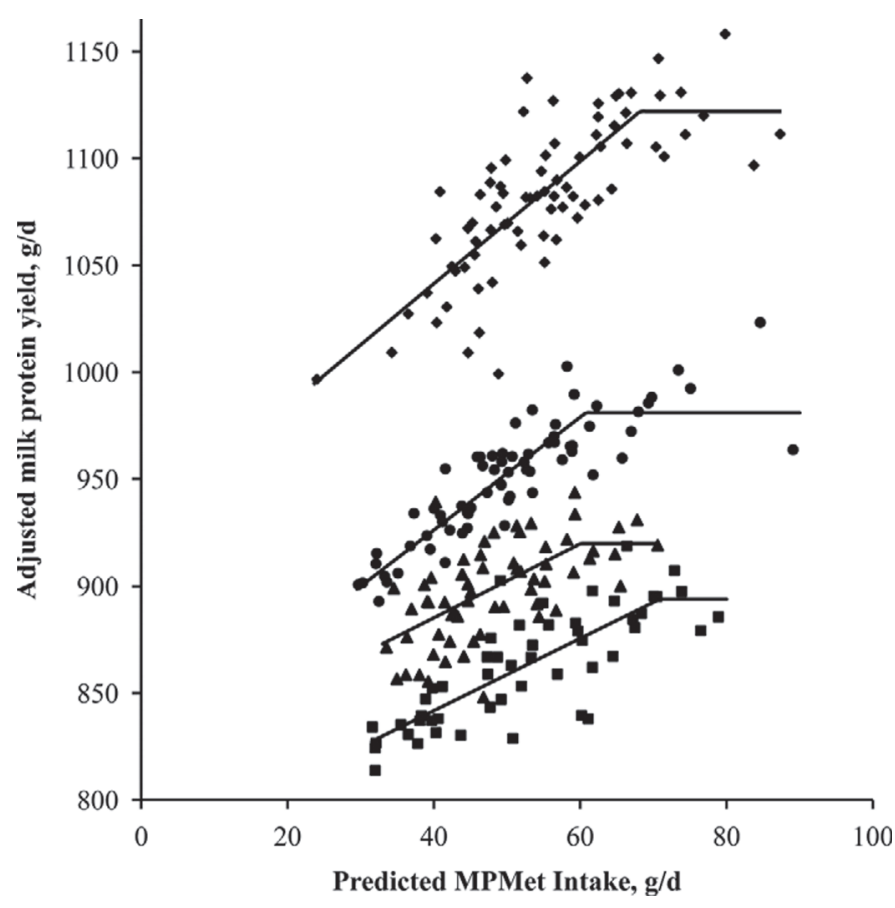

Figure 2. Adjusted (for random effects of trial) response in milk protein yield to increased supply of metabolizable methionine (MPMet) provided to cows through postruminal infusion with DLMet (ם) or supplemented with 2-hydroxy-4-methylthio butanoic acid (HMTBa; $\mathbf{\Delta}$ ), Mepron (Evonik Industries, Essen, Germany; $)$, or Smartamine (Adisseo Inc., Antony, France; $(\bullet)$. Maximum milk protein yield differed $(P<0.05)$, but the breakpoint and slope were not different between sources $(P>0.05)$. with a marginal efficiency of 15.3 (Doepel et al., 2004), $12 \mathrm{~g}$ of MP Met would result in an expected milk protein production response of $184 \mathrm{~g}$ of milk protein $(12 \times$ 15.3). This expected average response exceeds all of the maximum responses observed from any source. With a marginal efficiency of $2.3 \mathrm{~g}$ of increased milk protein per gram of increased MP Met, $12 \mathrm{~g}$ of MP Met would result in $27.6 \mathrm{~g}$ of milk protein, more closely approximating the average response to supplementation of 20.8 $\mathrm{g}$ of milk protein across sources and levels.

Nutritional and statistical reasons potentially account for the discrepancy in the observed marginal efficiencies. Nutritionally, Doepel et al. (2004) included results from both single AA infusions as well as those that infused multiple AA (i.e., casein). Combining these nutritionally distinct infusions into one analysis may result in a different marginal efficiency than if responses to each were analyzed individually. For instance, Schwab et al. (1976) determined that isomethionine abomasal infusion of Met or Met and Lys resulted in, on average, less than half of the response in milk protein output compared with the positive control infusions of 10 essential AA or sodium caseinate. The statistical difference between the current analysis and that of Doepel et al. (2004) is that the current analysis accounted for random effects of experiment in the slope and maximum parameter estimates, whereas Doepel et al. (2004) presented results from the fixed effects models only. Given the large differences in the production in the control cows in the current analysis, it is believed that accounting for the random effect of trial will lead to a more accurate representation of the response to supplementing MP Met alone in a new population of cows.

The analysis of Vyas and Erdman (2009) was a mixed effect logistic meta-analysis, which took into account 
Table 7. Parameter estimates of the mixed effect analysis of milk fat yield to increasing intake of metabolizable methionine (MPMet) provided to cows through postruminal infusion with DL-Met or supplemented with HMTBa, Mepron, or Smartamine ${ }^{1}$

\begin{tabular}{|c|c|c|c|c|c|c|}
\hline Item & DL-Met & HMTBa & Mepron & Smartamine & $\begin{array}{c}\text { Overall } \\
\text { estimate }^{2}\end{array}$ & $P$-value ${ }^{3}$ \\
\hline Intercept, $\mathrm{g}$ of milk fat & $1,054^{\mathrm{a}}$ & $777^{\mathrm{b}}$ & $1,132^{\mathrm{a}}$ & $1,116^{\mathrm{a}}$ & & \\
\hline Linear slope, $\Delta \mathrm{g}$ of milk fat $/ \Delta \mathrm{g}$ of MPMet & $2.09^{\mathrm{b}}$ & $5.38^{\mathrm{a}}$ & $1.64^{\mathrm{b}}$ & $1.89^{\mathrm{b}}$ & & \\
\hline $\mathrm{SE}$ & 1.04 & 1.07 & 0.77 & 0.83 & & 0.041 \\
\hline$P$-value & 0.048 & $<0.001$ & 0.034 & 0.025 & & \\
\hline
\end{tabular}

${ }^{\mathrm{a}, \mathrm{b}}$ Within a row, means with different superscripts are different at $P<0.05$.

${ }^{1} \mathrm{HMTBa}=$ 2-hydroxy-4-methylthio butanoic acid; Mepron (Evonik Industries, Essen, Germany) and Smartamine (Adisseo Inc., Antony, France).

${ }^{2}$ Parameter estimate for the overall response where methionine sources are combined when $P>0.05$; all $P$-values were $<0.05$.

${ }^{3} P$-values associated with the overall test of differences in parameter estimates between sources.

the random effect of trial. However, the model that was presented in that analysis appears to account for the random effect of trial as additive to the residual variance and not associated with the parameters of the logistic model. Accounting for the random effect of trial within the parameters of the model, especially when the ceiling of the response is determined multiplicatively (as it is in the logistic model), allows for a structural accounting of the variance associated with trial (i.e., the random effects of trial affect the parameter estimates of the function more than the residual).

The marginal responses of the supplemental sources were not significantly different than the marginal response observed due to DL-Met infusion (Table 6). From this it can be inferred that, after accounting for rumen degradation and intestinal digestibility using the values of the current analysis, MP Met from the different sources provides similar responses in milk protein yield. The lack of differences among sources to additional MP Met in the present analysis is for the most part consistent with the results where the response to supplementation was simply modeled. The exception would be the higher response to Mepron supplementation than what was observed due to the other supplements or to infused DL-Met. The difference between the 2 methodologies is that when evaluating response to supplementation over the control, the level of MP Met in the control diet and that provided by the supplement are not accounted for in the response, whereas our analysis takes the Met status of the control cows and the supplemented cows into consideration. Contribution of HMTBa toward MP Met has been a topic of controversy in the literature and industry. In addition to providing MP Met, HMTBa has been demonstrated to increase microbial protein synthesis in vitro (Gil et al., 1973; Sloan et al., 2000; Vázquez-Añón et al., 2001). This effect could result in greater flow of MP or potentially limiting AA in diets where HMTBa is fed.
However, the results of this analysis do not support a response in milk protein yield that is distinguishable from that which would be predicted from MP Met contributed by HMTBa when using a $40 \%$ rumen escape value. The biological mechanism contributing to the observed responses for these supplements cannot be determined from this meta-analysis.

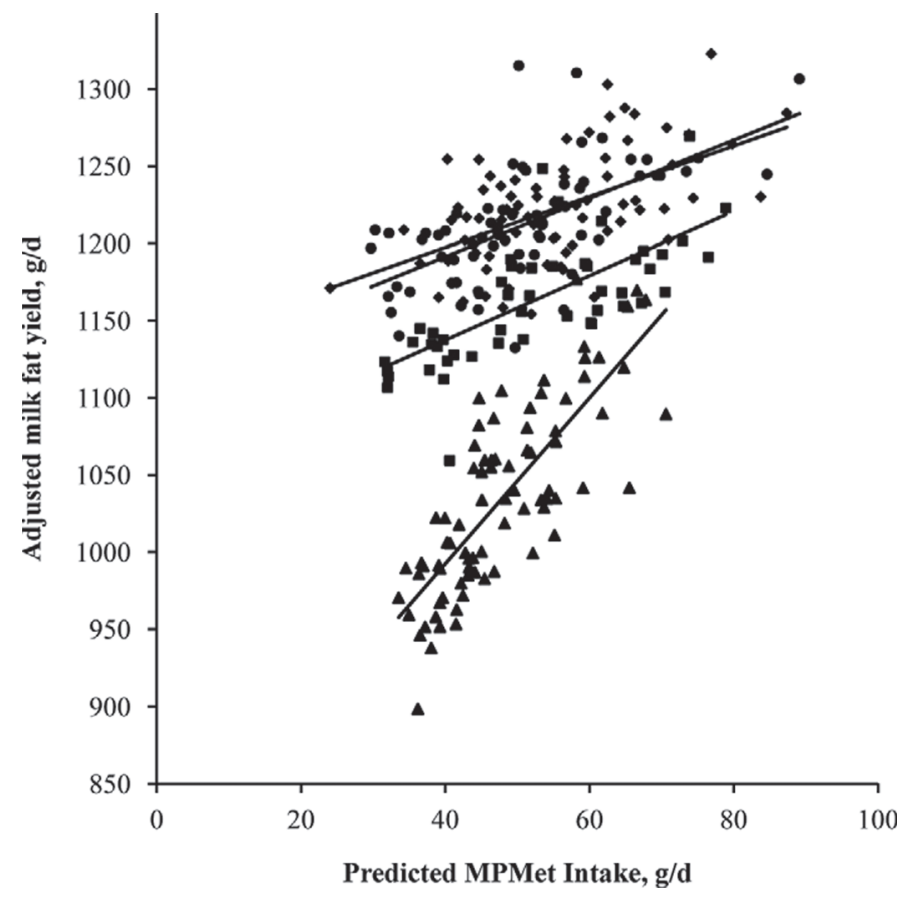

Figure 3. Adjusted (for random effects of trial) response in milk fat yield to increased supply of metabolizable methionine (MPMet) provided to cows through postruminal infusion with DL-Met (ם) or supplemented with 2-hydroxy-4-methylthio butanoic acid (HMTBa; ム), Mepron (Evonik Industries, Essen, Germany; $\bullet$ ), or Smartamine (Adisseo Inc., Antony, France; $\bullet$ ). Slope for HMTBa was higher and intercept was lower $(P<0.05)$ compared with the other sources, which did not differ from each other. 
As seen in Figure 1, the response in milk fat yield due to MP Met supplementation or infusion is less consistent than that for milk protein yield. For all sources, supplementation resulted in a significant increase in milk fat yield due to increasing MP Met (Figure 3). The parameter estimates for these response functions did not differ from each other (Table 7), with the exception of the parameter estimate for HMTBa. For the Met sources other than HMTBa, the marginal response to supplementation averaged approximately $1.9 \mathrm{~g}$ of increased milk fat per gram of additional MP Met. The intercept for HMTBa was significantly lower and the slope was significantly higher due to supplementation (5.38 $\mathrm{g}$ of milk fat/g of MP Met) than for the other sources or for DL-Met infusion. As previously discussed, many of the initial studies evaluating HMTBa feeding were designed with diets to test a hypothesis surrounding overcoming milk fat depression induced by feeding increased levels of concentrate. This difference in experimental objectives may account for some of the differences in the intercept and slope that was observed in the linear analysis. That Met, even when infused, can result in increased production of milk fat is of interest and would not be predicted based on the role of Met as a precursor to protein synthesis. In addition to the possible role of Met directly affecting milk fat, the effect of the experimental design affecting nutrient partitioning or body tissue mobilization cannot be excluded and would warrant further investigation. In explaining the differences between HMTBa and other Met sources, the possibility also exists that an effect occurring within the rumen is contributing to the greater marginal response. Thus, a portion of the response could be mediated by MP Met similarly to infused DL-Met and an additional portion of the response could be due to a rumen effect on factors such as biohydrogenation or the composition or growth of the rumen microbes. Insufficient data exists to accept or reject this hypothesis, but further study would be beneficial.

\section{CONCLUSIONS}

Infusing or supplementing cows with sources of MP Met resulted in increases in yield of both milk protein and fat. When response was compared with control, cows fed Mepron had greater increases in milk protein yield than the other sources; however, when the production response to increases in predicted MP Met relationship was evaluated, no differences in the production response to predicted MP Met was observed among sources. Milk fat yield response was significantly positive for HMTBa and Mepron compared with control diets; however, in the regression analysis to increasing predicted MP Met intake, the response was significantly different only for trials evaluating HMTBa.

\section{REFERENCES}

Ardalan, M., M. Dehghan-Banadaky, and K. Rezayazdi. 2010. Milk yield persistency and its relationship with health problems in Holstein dairy cows supplemented with different levels of ruminally protected methionine and choline. Archiv Tierzucht 53:266-276.

Armentano, L. E., S. J. Bertics, and G. A. Ducharme. 1997. Response of lactating cows to methionine or methionine plus lysine added to high protein diets based on alfalfa and heated soybeans. J. Dairy Sci. 80:1194-1199.

Benefield, B. C., R. A. Patton, M. J. Stevenson, and T. R. Overton. 2009. Evaluation of rumen-protected methionine sources and period length on performance of lactating dairy cows within Latin squares. J. Dairy Sci. 92:4448-4455.

Benevenga, N. J. 1974. Toxicities of methionine and other amino acids. J. Agric. Food Chem. 22:2-9.

Bequette, B. J., M. D. Hanigan, A. G. Calder, C. K. Reynolds, G E. Lobley, and J. C. MacRae. 2000. Amino acid exchange by the mammary gland of lactating goats when histidine limits milk production. J. Dairy Sci. 83:765-775.

Berthiaume, R., P. Dubreuil, M. Stevenson, B. W. McBride, and H. Lapierre. 2001. Intestinal disappearance and mesenteric and portal appearance of amino acids in dairy cows fed ruminally protected methionine. J. Dairy Sci. 84:194-203.

Berthiaume, R., M. C. Thivierge, R. A. Patton, P. Dubreuil, M. Stevenson, B. W. McBride, and H. Lapierre. 2006. Effect of ruminally protected methionine on splanchnic metabolism of amino acids in lactating dairy cows. J. Dairy Sci. 89:1621-1634.

Bhargava, P. K., D. E. Otterby, J. M. Murphy, and J. D. Donker. 1977. Methionine hydroxy analog in diets for lactating cows. J. Dairy Sci. 60:1594-1604

Blum, J. W., R. M. Bruckmaier, and F. Jans. 1999. Rumen-protected methionine fed to dairy cows: Bioavailability and effects on plasma amino acid pattern and plasma metabolite and insulin concentrations. J. Dairy Sci. 82:1991-1998.

Broderick, G. A., and R. E. Muck. 2009. Effect of alfalfa silage storage structure and rumen-protected methionine on production in lactating dairy cows. J. Dairy Sci. 92:1281-1289.

Broderick, G. A., M. J. Stevenson, and R. A. Patton. 2009. Effect of dietary protein concentration and degradability on response to rumen-protected methionine in lactating dairy cows. J. Dairy Sci. 92:2719-2728.

Broderick, G. A., M. J. Stevenson, R. A. Patton, N. E. Lobos, and J. J. Olmos Colmenero. 2008. Effect of supplementing rumen-protected methionine on production and nitrogen excretion in lactating dairy cows. J. Dairy Sci. 91:1092-1102.

Brosnan, J. T., and M. E. Brosnan. 2006. The sulfur-containing amino acids: An overview. J. Nutr. 136:1636S-1640S.

Chen, Z. H., G. A. Broderick, N. D. Luchini, B. K. Sloan, and E. Devillard. 2011. Effect of feeding different sources of rumen-protected methionine on milk production and N-utilization in lactating dairy cows. J. Dairy Sci. 94:1978-1988.

Chilliard, Y., and M. Doreau. 1997. Influence of supplementary fish oil and rumen-protected methionine on milk yield and composition in dairy cows. J. Dairy Res. 64:173-179.

Davidson, S., B. A. Hopkins, J. Odle, C. Brownie, V. Fellner, and L. W. Whitlow. 2008. Supplementing limited methionine diets with rumen-protected methionine, betaine, and choline in early lactation Holstein cows. J. Dairy Sci. 91:1552-1559.

Doepel, L., D. Pacheco, J. J. Kennelly, M. D. Hanigan, I. F. López, and H. Lapierre. 2004. Milk protein synthesis as a function of amino acid supply. J. Dairy Sci. 87:1279-1297.

Emmanuel, B., and J. J. Kennelly. 1984. Kinetics of methionine and choline and their incorporation into plasma lipids and milk components in lactating goats. J. Dairy Sci. 67:1912-1918. 
Gil, L. A., R. L. Shirley, and J. E. Moore. 1973. Effect of methionine hydroxy analog on growth, amino acid content, and catabolic products of glucolytic rumen bacteria in vitro. J. Dairy Sci. 56:757-762.

Girard, C. L., H. Lapierre, J. J. Matte, and G. E. Lobley. 2005. Effects of dietary supplements of folic acid and rumen-protected methionine on lactational performance and folate metabolism of dairy cows. J. Dairy Sci. 88:660-670.

Guinard, J., and H. Rulquin. 1995. Effects of graded amounts of duodenal infusions of methionine on the mammary uptake of major milk precursors in dairy cows. J. Dairy Sci. 78:2196-2207.

Guinard, J., H. Rulquin, and R. Vérité. 1994. Effect of graded levels of duodenal infusions of casein on mammary uptake in lactating cows. 1. Major nutrients. J. Dairy Sci. 77:2221-2231.

Gujarati, D. 1970. Use of dummy variables in testing for equality between sets of coefficients in linear regressions: A generalization. Am. Stat. 24:18-22.

Hansen, W. P., D. E. Otterby, J. G. Linn, and J. D. Donker. 1991. Influence of forage type, ratio of forage to concentrate, and methionine hydroxy analog on performance of dairy cows. J. Dairy Sci. 74:1361-1369.

Holter, J. B., C. W. Kim, and N. F. Colovos. 1972. Methionine hydroxy analog for lactating dairy cows. J. Dairy Sci. 55:460-465.

Huber, J. T., R. S. Emery, W. G. Bergen, J. S. Liesman, L. Kung Jr., K. J. King, R. W. Gardner, and M. Checketts. 1984. Influences of methionine hydroxy analog on milk and milk fat production, blood serum lipids, and plasma amino acids. J. Dairy Sci. 67:2525-2531.

Hutjens, M. F., and L. H. Schultz. 1971. Addition of soybeans or methionine analog to high-concentrate rations for dairy cows. J. Dairy Sci. 54:1637-1644.

Koenig, K. M., L. M. Rode, C. D. Knight, and P. R. McCullough. 1999. Ruminal escape, gastrointestinal absorption, and response of serum methionine to supplementation of liquid methionine hydroxy analog in dairy cows. J. Dairy Sci. 82:355-361.

Koenig, K. M., L. M. Rode, C. D. Knight, and M. Vázquez-Añón. 2002. Rumen degradation and availability of various amounts of liquid methionine hydroxy analog in lactating dairy cows. J. Dairy Sci. 85:930-938.

Kowalski, Z. M., and P. M. Pisulewski. 2003. Effects of protected methionine and variable energy supply on lactational responses in dairy cows fed grass silage-based diets. J. Anim. Feed Sci. 12:451-464.

Kowalski, Z. M., P. M. Pisulewski, and M. Spanghero. 1999. Effects of calcium soaps of rapeseed fatty acids and protected methionine on milk yield and composition in dairy cows. J. Dairy Res. 66:475-487.

Kröber, T. F., M. Kreuzer, M. Senn, W. Langhans, and F. Sutter. 2000. Lactational and metabolic effects in cows of lysine and methionine added to a ration deficient according to the I.N.R.A. method. Arch. Tierernaehrung 53:375-394.

Kudrna, V., J. Illek, M. Marounek, and A. Nguyen Ngoc. 2009. Feeding ruminally protected methionine to pre- and postpartum dairy cows: effect on milk performance, milk composition and blood parameters. Czech J. Anim. Sci. 54:395-402.

Lapierre, H., D. Pacheco, R. Berthiaume, D. R. Ouellet, C. G. Schwab, P. Dubreuil, G. Holtrop, and G. E. Lobley. 2006. What is the true supply of amino acids for a dairy cow? J. Dairy Sci. 89(Suppl. 1):E1-E14.

Lara, A., G. D. Mendoza, L. Landois, R. Barcena, M. T. SánchezTorres, R. Rojo, J. Ayala, and S. Vega. 2006. Milk production in Holstein cows supplemented with different levels of ruminally protected methionine. Livest. Sci. 105:105-108.

Lean, I. J., A. R. Rabiee, T. F. Duffield, and I. R. Dohoo. 2009. Invited review: Use of meta-analysis in animal health and reproduction: methods and applications. J. Dairy Sci. 92:3545-3565.

Leonardi, C., M. Stevenson, and L. E. Armentano. 2003. Effect of two levels of crude protein and methionine supplementation on performance of dairy cows. J. Dairy Sci. 86:4033-4042.

Lundquist, R. G., J. G. Linn, and D. E. Otterby. 1983. Influence of dietary energy and protein on yield and composition of milk from cows fed methionine hydroxy analog. J. Dairy Sci. 66:475-491.
Lundquist, R. G., D. E. Otterby, and J. G. Linn. 1985. Influence of three concentrations of DL-methionine or methionine hydroxy ana$\log$ on milk yield and milk composition. J. Dairy Sci. 68:33503354 .

McCarthy, R. D., G. A. Porter, and L. C. Griel. 1968. Bovine ketosis and depressed fat test in milk: A problem of methionine metabolism and serum lipoprotein aberration. J. Dairy Sci. 51:459-462.

Misciatteilli, L., V. F. Kristensen, M. Vestergaard, M. R. Weisbjerg, K. Sejrsen, and T. Hvelplund. 2003. Milk production, nutrient utilization, and endocrine responses to increased postruminal lysine and methionine supply in dairy cows. J. Dairy Sci. 86:275-286.

Noftsger, S., N. R. St-Pierre, and J. T. Sylvester. 2005. Determination of rumen degradability and ruminal effects of three sources of methionine in lactating cows. J. Dairy Sci. 88:223-237.

NRC. 2001. Nutrient requirements of dairy cattle. 11th ed. Natl. Acad. Sci., Washington, DC.

Ordway, R. S., S. E. Boucher, N. L. Whitehouse, C. G. Schwab, and B. K. Sloan. 2009. Effects of providing two forms of supplemental methionine to periparturient Holstein dairy cows on feed intake and lactational performance. J. Dairy Sci. 92:5154-5166.

Overton, T. R., L. S. Emmert, and J. H. Clark. 1998. Effects of source of carbohydrate and protein and rumen-protected methionine on performance of cows. J. Dairy Sci. 81:221-228.

Overton, T. R., D. W. Lacount, T. M. Cicela, and J. H. Clark. 1996. Evaluation of a ruminally protected methionine product for lactating dairy cows. J. Dairy Sci. 79:631-638.

Pacheco, D., R. A. Patton, C. Parys, and H. Lapierre. 2012. Ability of commercially available dairy ration programs to predict duodenal flows of protein and essential amino acids in dairy cows. J. Dairy Sci. 95:937-963.

Papas, A. M., C. J. Sniffen, and T. V. Muscato. 1984a. Effectiveness of rumen-protected methionine for delivering methionine postruminally in dairy cows. J. Dairy Sci. 67:545-552.

Papas, A. M., J. L. Vicini, J. H. Clark, and S. Peirce-Sandner. 1984b. Effect of rumen-protected methionine on plasma free amino acids and production by dairy cows. J. Nutr. 114:2221-2227.

Patton, R. A. 2010. Effect of rumen-protected methionine on feed intake, milk production, true milk protein concentration, and true milk protein yield, and the factors that influence these effects: A meta-analysis. J. Dairy Sci. 93:2105-2118.

Phillips, G. J., T. L. Citron, J. S. Sage, K. A. Cummins, M. J. Cecava, and J. P. McNamara. 2003. Adaptations in body muscle and fat in transition dairy cattle fed differing amounts of protein and methionine hydroxy analog. J. Dairy Sci. 86:3634-3647.

Piepenbrink, M. S., A. L. Marr, M. R. Waldron, W. R. Butler, T. R. Overton, M. Vázquez-Añón, and M. D. Holt. 2004. Feeding 2-hydroxy-4-(methylthio)-butanoic acid to periparturient dairy cows improves milk production but not hepatic metabolism. J. Dairy Sci. 87:1071-1084.

Pisulewski, P. M., and Z. Kowalski. 1999. The effect of protected lysine and methionine on milk yield and its composition in lactating dairy cows fed grass silage-based rations. J. Anim. Feed Sci. 8:341-353.

Pisulewski, P. M., and Z. Kowalski. 2002. Lactational responses to ruminally-protected methionine in cows fed a low-protein grass silage-based diet. J. Anim. Feed Sci. 11:189-203.

Pisulewski, P. M., H. Rulquin, J. L. Peyraud, and R. Verite. 1996. Lactational and systemic responses of dairy cows to postruminal infusions of increasing amounts of methionine. J. Dairy Sci. 79:1781-1791.

Polan, C. E., P. T. Chandler, and C. N. Miller. 1970. Methionine hydroxy analog: Varying levels for lactating cows. J. Dairy Sci. 53:607-610.

Polan, C. E., K. A. Cummins, C. J. Sniffen, T. V. Muscato, J. L. Vicini, B. A. Crooker, J. H. Clark, D. G. Johnson, D. E. Otterby, B. Guillaume, L. D. Muller, G. A. Varga, R. A. Murray, and S. B. Peirce-Sandner. 1991. Responses of dairy cows to supplemental rumen-protected forms of methionine and lysine. J. Dairy Sci. 74:2997-3013.

Preynat, A., H. Lapierre, M. C. Thivierge, M. F. Palin, J. J. Matte, A. Desrochers, and C. L. Girard. 2009a. Effects of supplements 
of folic acid, vitamin B12, and rumen-protected methionine on whole body metabolism of methionine and glucose in lactating dairy cows. J. Dairy Sci. 92:677-689.

Preynat, A., H. Lapierre, M. C. Thivierge, M. F. Palin, J. J. Matte, A. Desrochers, and C. L. Girard. 2009b. Influence of methionine supply on the response of lactational performance of dairy cows to supplementary folic acid and vitamin B12. J. Dairy Sci. 92:16851695.

Pruekvimolphan, S., and R. R. Grummer. 2001. Lactation responses to sulfur-containing amino acids from feather meal or rumen-protected methionine. J. Dairy Sci. 84:2515-2522.

Robbins, K. R., A. M. Saxton, and L. L. Southern. 2006. Estimation of nutrient requirements using broken-line regression analysis. J. Anim. Sci. 84(E-Suppl.):E155-E165.

Robinson, P. H. 2010. Impacts of manipulating ration metabolizable lysine and methionine levels on the performance of lactating dairy cows: A systematic review of the literature. Livest. Sci. 127:115126.

Robinson, P. H., W. Chalupa, C. J. Sniffen, W. E. Julien, H. Sato, T. Fujieda, T. Ueda, and H. Suzuki. 2000. Influence of abomasal infusion of high levels of lysine or methionine, or both, on ruminal fermentation, eating behavior, and performance of lactating dairy cows. J. Anim. Sci. 78:1067-1077.

Rosser, R. A., C. E. Polan, P. T. Chandler, and T. L. Bibb. 1971. Effects of whey components and methionine analog on bovine milk fat production. J. Dairy Sci. 54:1807-1816.

Rulquin, H., and L. Delaby. 1997. Effects of the energy balance of dairy cows on lactational responses to rumen-protected methionine. J. Dairy Sci. 80:2513-2522.

Rulquin, H., B. Graulet, L. Delaby, and J. C. Robert. 2006. Effect of different forms of methionine on lactational performance of dairy cows. J. Dairy Sci. 89:4387-4394.

Rulquin, H., P. Pisulewski, R. Vérité, and J. Guinard. 1993. Milk production and composition as a function of postruminal lysine and methionine supply: A nutrient-response approach. Livest. Prod. Sci. 37:69-90.

Samuelson, D. J., S. K. Denise, R. Roffler, R. L. Ax, D. V. Armstrong, and D. F. Romagnolo. 2001. Response of Holstein and Brown Swiss cows fed alfalfa hay-based diets to supplemental methionine at two stages of lactation. J. Dairy Sci. 84:917-928.

SAS Institute. 2011. SAS/STAT User's Guide. Release 9.2. SAS Institute Inc., Cary, NC.

Schwab, C., N. Whitehouse, A. M. McLaughlin, R. K. Kadariya, N. R. St-Pierre, B. K. Sloan, R. M. Gill, and J. C. Robert. 2001. Use of milk protein concentrations to estimate the "methionine bioavailability" of two forms of 2 hydroxy-4-methythio butanoic acid (HMB) for lactating cows. J. Dairy Sci. 84(Suppl. 1):35. (Abstr.)

Schwab, C. G., C. K. Bozak, N. L. Whitehouse, and M. M. Mesbah. 1992. Amino acid limitation and flow to duodenum at four stages of lactation. 1. Sequence of lysine and methionine limitation. J. Dairy Sci. 75:3486-3502.

Schwab, C. G., L. D. Satter, and A. B. Clay. 1976. Response of lactating dairy cows to abomasal infusion of amino acids. J. Dairy Sci. 59:1254-1270.

Sharma, B. K., and R. A. Erdman. 1988. Abomasal infusion of choline and methionine with or without 2-amino-2-methyl-1-propanol for lactating dairy cows. J. Dairy Sci. 71:2406-2411.

Sloan, B. K., W. H. Hoover, T. K. Miller Webster, C. G. Schwab, and N. L. Whitehouse. 2000. Action of hydroxy methyl butanoic acid (HMB) on microbial growth and metabolism. J. Dairy Sci. 83(Suppl. 1):269. (Abstr.)
Socha, M. T., D. E. Putnam, B. D. Garthwaite, N. L. Whitehouse, N A. Kierstead, C. G. Schwab, G. A. Ducharme, and J. C. Robert 2005. Improving intestinal amino acid supply of pre- and postpartum dairy cows with rumen-protected methionine and lysine. J. Dairy Sci. 88:1113-1126.

Socha, M. T., C. G. Schwab, D. E. Putnam, N. L. Whitehouse, B. D. Garthwaite, and G. A. Ducharme. 2008. Extent of methionine limitation in peak-, early-, and mid-lactation dairy cows. J. Dairy Sci. 91:1996-2010.

Soder, K. J., and L. A. Holden. 1999. Lymphocyte proliferation response of lactating dairy cows fed varying concentrations of rumen-protected methionine. J. Dairy Sci. 82:1935-1942.

St-Pierre, N. R. 2001. Invited review: Integrating quantitative findings from multiple studies using mixed model methodology. J. Dairy Sci. 84:741-755.

St-Pierre, N. R., and J. T. Sylvester. 2005. Effects of 2-hydroxy4-(methylthio) butanoic acid (HMB) and its isopropyl ester on milk production and composition by Holstein cows. J. Dairy Sci. 88:2487-2497.

Stokes, M. R., J. H. Clark, and L. M. Steinmetz. 1981. Performance of lactating dairy cows fed methionine or methionine analog at two concentrations of dietary crude protein. J. Dairy Sci. 64:16861694.

Suits, D. B. 1957. Use of dummy variables in regression equations. J. Am. Stat. Assoc. 52:548-551.

Vanhatalo, A., P. Huhtanen, V. Toivonen, and T. Varvikko. 1999. Response of dairy cows fed grass silage diets to abomasal infusions of histidine alone or in combinations with methionine and lysine. J. Dairy Sci. 82:2674-2685.

Varvikko, T., A. Vanhatalo, T. Jalava, and P. Huhtanen. 1999. Lactation and metabolic responses to graded abomasal doses of methionine and lysine in cows fed grass silage diets. J. Dairy Sci 82:2659-2673.

Vázquez-Añón, M., T. Cassidy, P. McCullough, and G. A. Varga. 2001. Effects of alimet on nutrient digestibility, bacterial protein synthesis, and ruminal disappearance during continuous culture. J. Dairy Sci. 84:159-166.

Vyas, D., and R. A. Erdman. 2009. Meta-analysis of milk protein yield responses to lysine and methionine supplementation. J. Dairy Sci. 92:5011-5018

Waghorn, G. C., and R. L. Baldwin. 1984. Model of metabolite flux within mammary gland of the lactating cow. J. Dairy Sci. 67:531544.

Wallenius, R. W., and R. E. Whitchurch. 1975. Methionine hydroxy analog or sulfate supplementation for high producing dairy cows. J. Dairy Sci. 58:1314-1319.

Wang, C., H. Y. Liu, Y. M. Wang, Z. Q. Yang, J. X. Liu, Y. M. Wu, T. Yan, and H. W. Ye. 2010. Effects of dietary supplementation of methionine and lysine on milk production and nitrogen utilization in dairy cows. J. Dairy Sci. 93:3661-3670.

Weekes, T. L., P. H. Luimes, and J. P. Cant. 2006. Responses to amino acid imbalances and deficiencies in lactating dairy cows. J. Dairy Sci. 89:2177-2187.

Zanton, G. I., S. E. Bettis, and M. Vazquez-Anon. 2012. Plasma responses to intra-ruminal or post-ruminal administration of 2-hydroxy-4-methylthio-butanoic acid and its isopropyl ester in dairy cattle to evaluate rumen escape. J. Dairy Sci. 95(Suppl. 2):346. (Abstr.) 
Table A1. Summary of papers meeting selection criteria

\section{APPENDIX}

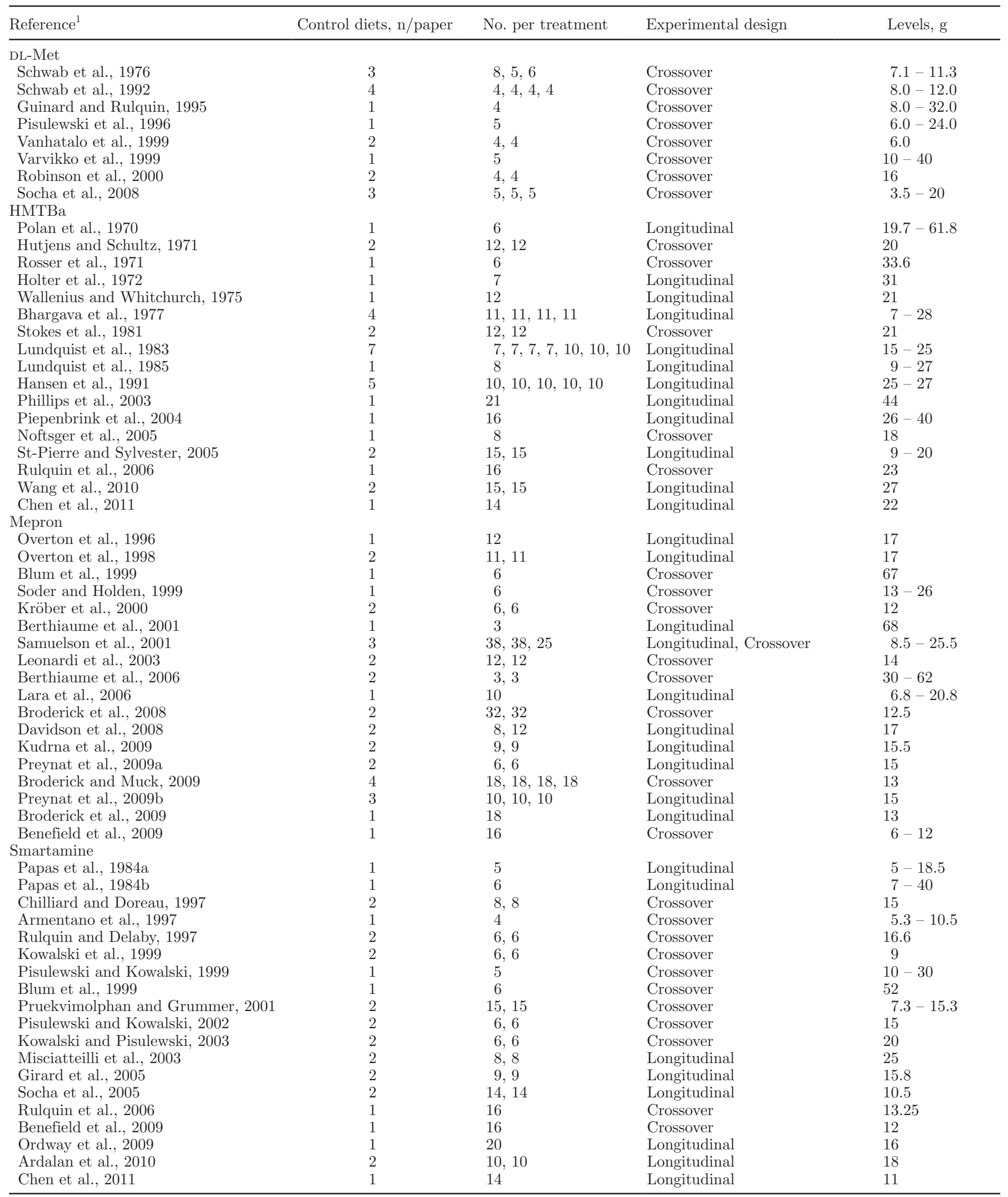

${ }^{1} \mathrm{HMTBa}=2$-hydroxy-4-methylthio butanoic acid; Mepron (Evonik Industries, Essen, Germany) and Smartamine (Adisseo Inc., Antony, France). 